\title{
Ready to Use Therapeutical Beverages: Focus on Functional Beverages Containing Probiotics, Prebiotics and Synbiotics
}

\author{
Amirhossein Nazhand ${ }^{1}$, Eliana B. Souto ${ }^{2,3}{ }^{1}$, Massimo Lucarini ${ }^{4}$, Selma B. Souto ${ }^{5}$, \\ Alessandra Durazzo ${ }^{4, *(D)}$ and Antonello Santini ${ }^{6, *(D)}$ \\ 1 Department of Biotechnology, Sari Agriculture Science and Natural Resource University, \\ 9th km of Farah Abad Road, Sari 48181 68984, Mazandaran, Iran; nazhand.ah@gmail.com \\ 2 Faculty of Pharmacy, University of Coimbra, Azinhaga de Santa Comba, Polo III-Saúde, \\ 3000-548 Coimbra, Portugal; souto.eliana@gmail.com \\ 3 CEB-Centre of Biological Engineering, University of Minho, Campus de Gualtar, 4710-057 Braga, Portugal \\ 4 CREA-Research Centre for Food and Nutrition, Via Ardeatina 546, 00178 Roma, Italy; \\ massimo.lucarini@crea.gov.it \\ 5 Department of Endocrinology, Hospital São João, Alameda Prof. Hernâni Monteiro, \\ 4200-319 Porto, Portugal; sbsouto.md@gmail.com \\ 6 Department of Pharmacy, University of Napoli Federico II, Via D. Montesano 49, 80131 Napoli, Italy \\ * Correspondence: alessandra.durazzo@crea.gov.it (A.D.); asantini@unina.it (A.S.); \\ Tel.: +39-6-51494430 (A.D.); +39-81-2539317 (A.S.)
}

Received: 11 February 2020; Accepted: 13 April 2020; Published: 20 April 2020

\begin{abstract}
The growing global interest in functional foods containing nutrients capable of adding possible beneficial health effects is rapidly increasing both interest and consumer demand. In particular, functionalized beverages for their potential positive effect on health e.g., decreasing cholesterol level, lowering sugar, high fiber content, ability to enhance the immune system, and help digestion, have recently received special attention. Among the different beverages available on the market, probiotic dairy and non-dairy products have attracted much attention because of their affordable cost and their numerous therapeutic activities. Fermented milk and yogurt are currently worth $€ 46$ billion, with $77 \%$ of the market reported in Europe, North America, and Asia. Consumption of dairy beverages has some limitations due for example to lactose intolerance and allergy to milk proteins, thereby leading consumers to use non-dairy beverages such as fruit, grains, and vegetable juices to add probiotics to diet as well as driving the manufacturers to food matrices-based beverages containing probiotic cultures. The purpose of this review article is to evaluate the therapeutic performance and properties of dairy and non-dairy beverages in terms of probiotic, prebiotic, and synbiotic activities.
\end{abstract}

Keywords: beverages; probiotics; health; functional food; prebiotics; synbiotics

\section{Introduction}

Beverages make important contributions to nutritional intake, and their role in health has recently received much attention. Beverages meet consumers' demands in terms of size, shape, storage, and possibility to contain desirable nutrients and bioactive compounds [1]. Recently, Ghoshal et al. [2] discussed beverages as a source of nutraceuticals [3-17], clearing classification, importance, health benefits, interaction with the food, retention during storage, and delivery in the human body. Ingredients of functional beverages include vitamins, minerals, essential fatty acids, amino acids, and herbs. Functional beverages can be useful to support the immune system, improve gut or cardiovascular health, help in weight management, or act as an adjuvant to counteract the aging processes. 
Functional beverages can be classified as dairy-based beverages (including probiotics and mineral enriched drinks), vegetable and fruit beverages, and sports and energy drinks [18]. A scheme is shown in Figure 1. Several types of commercial products are available on the market and are identified as sport and energy drinks or as enriched beverages. Nutraceuticals providing specific health benefits as well as drinkable probiotics containing supplements and dietetics drinks are also available on the market [19].

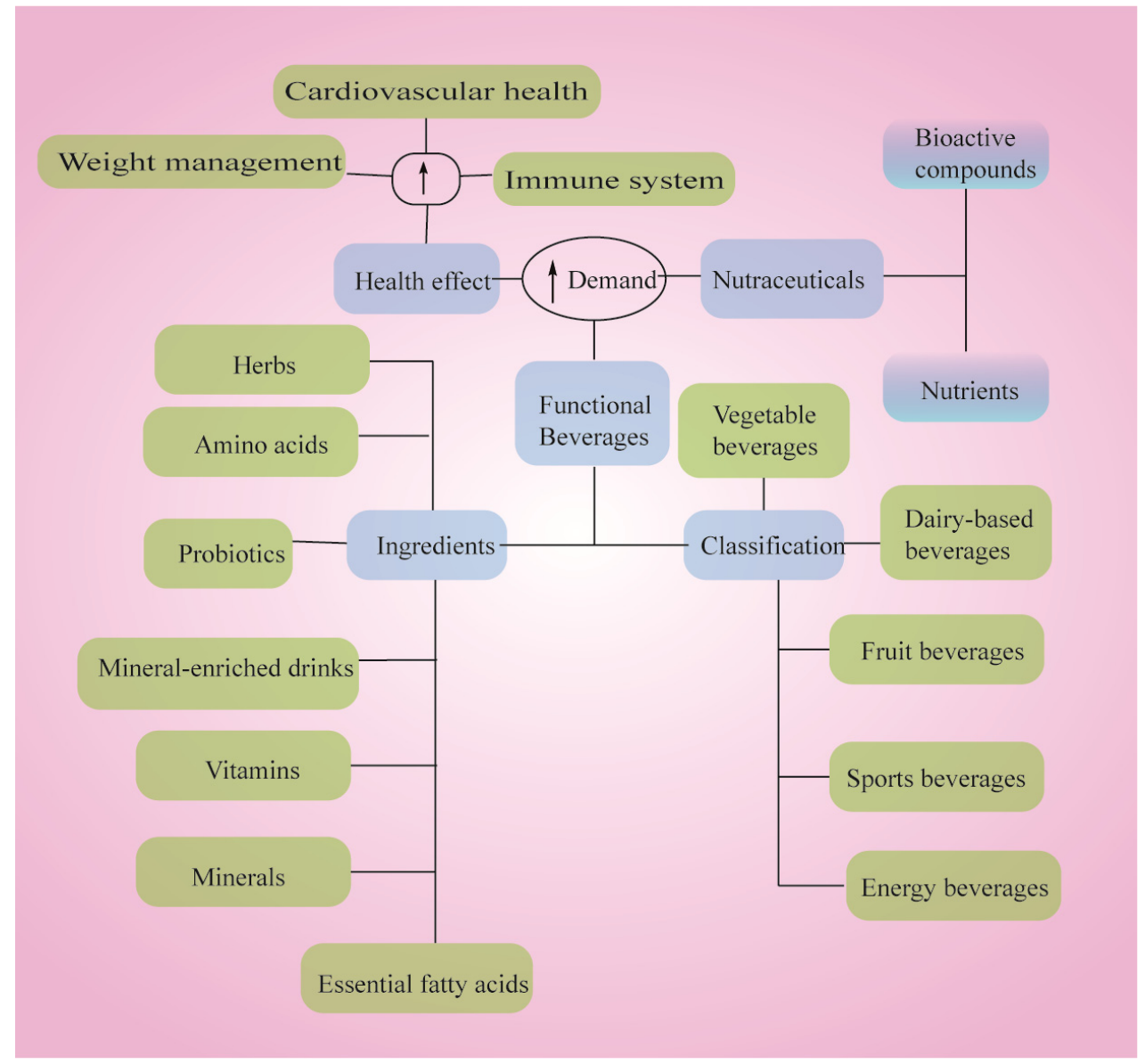

Figure 1. Scheme of functional beverages.

Orrù et al. [20] reviewed the current information available in the literature regarding micronutrient-enriched functional beverages in sport taking into account the athletes' health, sports performance, and recovery. Popular sports drinks represent a compromise that meets the needs of most people in several situations, even if no single formulation is able to fulfill all of them. Concerning dairy-based beverages, it is worth mentioning the review of Barbano et al. [21], which examined the last 100-years of the production of a wide range of types of milk available on the market ranging from skim and low-fat milks, to flavored milks, from lactose-reduced milk and long-shelf-life milks, to milks with higher protein and calcium contents. Particular reference has been given to the production technology of high-protein sports beverages. Sun-Waterhouse [22] overviewed the research opportunities in the emerging area of fruit-derived products. Butu and Rodino [23] exploited the synergies between raw materials as ingredients, processing methods, and product formulation as new directions and innovations in the natural vegetable and fruit beverages industry. Chandrasekara and Shahidi [24] described the main evidence concerning herbal beverages: these are prepared starting from natural ingredients belonging to different morphological plant parts, namely leaves, stems, roots, fruits, buds, and flowers. Herbal teas/beverages are rich sources of natural bioactive compounds, such as 
carotenoids, phenolic acids, flavonoids, coumarins, alkaloids, polyacetylenes, saponins, and terpenoids, among the others [24].

The demand for fresh and natural eco-sustainable products with appealing sensory characteristics and high nutritional value is exponentially growing, as well as the market demand [25]. Meanwhile, fermented functional foods have attracted much attention for their positive effects on human health $[18,25,26]$. To this last area belong also foods or beverages with controlled microbial growth and enzymatic reactions, known as fermented foods [27]. The human consumption of fermented beverages, dating back many years as a main part of a daily diet, has formed the fastest-growing segment of the US food market in 2017 ( $\$ 1347$ billion) [28-30]. Being a low-cost technology, the fermentation plays a relevant role in preserving and enhancing the nutritional value and sensory properties of foods, demonstrating the global importance of fermented beverages containing probiotic bacteria for the human diet [31,32]. There is a wide variety of pre- and pro-biotics, e.g., dairy and non-dairy beverages with high therapeutic efficacy, including cardiovascular system enhancement, weight loss, healthy effect on the digestive tract, boosting immune defense, antioxidant activity, cancer prevention, and improved joint function [33-42]. Accordingly, the present review article has been focused on the evaluation of the positive impact of dairy and non-dairy beverages on human health by considering their probiotic, prebiotic, and synbiotic activities.

\section{Beneficial Health Effects and Properties of Dairy and Non-Dairy Beverages Containing Probiotics, Prebiotics and Synbiotics: An Updated Shot}

The increasing human consumption of probiotic foods can be attributed to the consumers' interest in foods that contain substances beneficial for health [43-45], and this is reflected in the worldwide sales of probiotic foods: global sales rose to $\$ 24.2$ billion from $\$ 21.6$ billion between 2010 and 2011 . It may be estimated that the sales will rise up to $\$ 96$ trillion in the year 2020 [46]. This has led food industry researchers to produce new probiotic-containing foods. Therefore, Europe is at the forefront of this market due to the wide range of probiotic foodstuffs produced, such as yogurt, butter, cheese, dairy beverages, ice cream, fruit juices, recovery drinks, and cereal drinks. In fact, sales of these products were observed as $\$ 616.13$ million in 2018 at a Compound Annual Growth Rate (CAGR) of $7.7 \%$ from 2013 to 2018 [47].

Many of the beneficial effects of such beverages are related to the different types of bacteria, molds, and yeasts known as probiotics, mainly Bifidobacterium and Lactobacillus ssp. [48-52]. The probiotics are living microorganisms with positive properties for the host's health if consumed in sufficient quantities [52]. The International Scientific Association of Probiotics and Prebiotics has documented that prebiotics are fermented selective substances that result in specific changes in the composition and/or activity of the gastrointestinal microbiota, thereby positively affecting the health of the host in favor of beneficial bacteria constituting the microbiota [53,54]. The synbiotics refers to the combination of prebiotics plus probiotics, which have positive effects on host health through the promotion of beneficial microbial colonization and survival in the host gut [55]. Therefore, synbiotics have been developed to manage some potential problems in the survival of probiotics in the gastrointestinal tract, and they can act as both probiotics and prebiotics [55]. The probiotic cultures can survive in functional drinks mediated by a variety of factors, such as hydrogen peroxide $\left(\mathrm{H}_{2} \mathrm{O}_{2}\right)$, dissolved oxygen (DO), redox potential, $\mathrm{pH}$, and acidity [56]. The probiotics have been reported to have beneficial effects on health [57-59], such as the increased activity of some enzymes, enhancement of intestinal barrier function, generation or induction of antibacterial or bacteriocin-like substances and defensin, effect on host gut microbiota and pathogenic bacteria, alteration of $\mathrm{pH}$, competition for nutrients and physical barriers, modulation of host immune function, intestinal carcinogenesis, cholesterol uptake, and competitive deprivation of pathogenic bacteria [57-59]. In Table 1a-c is reported an updated shot of dairy and non-dairy beverages with prebiotic, probiotics, and synbiotics effects in in vitro, animals and human studies. 
Table 1. (a) In vitro studies; (b) in animal studies; (c) in human studies.

\begin{tabular}{|c|c|c|c|c|c|}
\hline \multicolumn{6}{|c|}{ (a) } \\
\hline Beverage & Condition & Product & Activity & Effect & Reference \\
\hline & & Kefir & Anti-oxidant activity & $\begin{array}{l}\text { Having fermentation observed DPPH radical scavenging, inhibition effect } \\
\text { upon linoleic acid autoxidation increased, accordingly, TPC, and inhibition } \\
\text { effect upon ascorbate autoxidation boosted }\end{array}$ & {$[60]$} \\
\hline & & Milk and yogurt along with red ginseng & $\begin{array}{l}\text { Anti-oxidant and Antigenotoxic } \\
\text { effect }\end{array}$ & $\begin{array}{c}\text { The 2,2-diphenyl-1-picrylhy- drazyl radical scavenging activity and oxygen } \\
\text { radical absorbance capacity values raised meaningfully in subsequence of } \\
\text { adding } 2 \% \text { red ginseng in both. }\end{array}$ & [61] \\
\hline \multirow[t]{8}{*}{ Dairy } & In vitro & Kefir & Antimicrobial activity & $\begin{array}{l}\text { Lactobacillus kefiri B6 has been reported having anti-pathogenic activity and } \\
\text { being resistant to bile }\end{array}$ & [62] \\
\hline & & Yogurt and ewe colostrum & Anticancer effects & $\begin{array}{l}\text { Antiproliferative effects detected against HT-29 human cancer cells by } \\
\text { Lactobacillus plantarum 17C }\end{array}$ & [63] \\
\hline & & Yogurt & Antioxidant activity & $\begin{array}{l}\text { Although Lactobacillus barbarum naturally sweetened the yogurt and increased } \\
\text { yogurt aroma, it did not enhance ACE-I prevention activity }\end{array}$ & [64] \\
\hline & & Kefir & The immunomodulatory effect & $\begin{array}{l}\text { The activation of intestinal epithelial cells triggered prevented via flagellin, } \\
\text { interleukin-1 } \beta \text {, and tumor necrosis factor- } \alpha \text { as well as abrogates NF-kB } \\
\text { signaling in the cells }\end{array}$ & {$[65]$} \\
\hline & & Papaya juices & Anti-oxidant activity & $\begin{array}{l}\begin{array}{l}\text { L. plantarum showed better antioxidant activity than L. acidophilus due to its } \\
\text { better oxidation resistance }\end{array}\end{array}$ & [66] \\
\hline & & Plant sterol (PS)-enriched beverages & $\begin{array}{l}\text { Elevation of phytosterol } \\
\text { oxidation products (POPs) }\end{array}$ & $\begin{array}{c}\text { There was more than } 75 \% \text { of total POPs during storage period for three } \\
\text { beverages enriched by plant sterol (PS). }\end{array}$ & [67] \\
\hline & & The fermented pineapple beverage & Sensory and nutritional aspects & $\begin{array}{l}\text { Further capacity was observed for Meyerozyma caribbica for general acceptance, } \\
\text { aroma and taste on the basis of sensorial findings }\end{array}$ & {$[68]$} \\
\hline & & Cereal beverages & Synbiotic effect & $\begin{array}{l}\text { The count of viable probiotics ( } \geq 107 \mathrm{CFU} / \mathrm{mL} \text { ) was found during refrigeration } \\
\text { and fermentation for } 28 \text { days while maintaining the prebiotic effect. }\end{array}$ & [69] \\
\hline \multirow[t]{4}{*}{ Non-Dairy } & In vitro & Blueberry beverages & $\begin{array}{l}\text { Controlled retinal pigment } \\
\text { epithelium (RPE) cells damage }\end{array}$ & $\begin{array}{l}\text { The extracts of blueberry anthocyanin protected the pigmented layer of the } \\
\text { retina against damages caused by light through the suppression of apoptosis } \\
\text { and aging as well as the down-regulation of vascular endothelial growth } \\
\text { factor expression to the normal limit. }\end{array}$ & [70] \\
\hline & & Apple juice & Antioxidant effect & $\begin{array}{c}\text { The analysis of antioxidant properties by DPPH assay in relation to radical } \\
\text { scavenging and FRAP functions }\end{array}$ & [71] \\
\hline & & Fermented beet-root juice & $\begin{array}{c}\text { Anticancer and } \\
\text { Antibacterial effect }\end{array}$ & HepG2 as human liver cancer cell line and Listeria monocytogenes controlled & [72] \\
\hline & & Fermented cereal beverages & Antimicrobial effect & $\begin{array}{l}\text { Antimicrobial properties were reported for Leuconostoc lactis BT17 to } \\
\text { control Enterobacteriaceae. }\end{array}$ & [73] \\
\hline
\end{tabular}


Table 1. Cont

\begin{tabular}{|c|c|c|c|c|c|c|c|}
\hline \multicolumn{8}{|c|}{ (b) } \\
\hline Beverage & Condition & Product & Activity & Subjects & Administration Time & Effect & Reference \\
\hline \multirow[t]{6}{*}{ Dairy } & $\begin{array}{l}\text { In animal } \\
\text { model }\end{array}$ & $\begin{array}{l}\text { Kefir fermented } \\
\text { milk }\end{array}$ & Bifidogenic effect & $\begin{array}{l}\text { Animal units were randomized } \\
\text { into two groups of } 6\end{array}$ & $\begin{array}{l}\text { Daily administration of } 0.75-1 \mathrm{mg} \text { of } \\
\text { kefiran/animal/day in the } \\
\text { intervention group }(\mathrm{n}=6)\end{array}$ & $\begin{array}{l}\text { The kefiran prebiotic effects on } \\
\text { intestinal bacterial populations by } \\
\text { increasing through bifidogenic }\end{array}$ & [74] \\
\hline & & Kefir & $\begin{array}{l}\text { Anti-inflammatory } \\
\text { in gut }\end{array}$ & $\begin{array}{l}\text { Male Swiss albino mice aged } \\
4 \text { weeks }(\mathrm{n}=12)\end{array}$ & $\begin{array}{l}\text { Daily administration of Kefir (with } \\
108 \mathrm{CFU} / \mathrm{mL} \text { of L. kefiri CIDCA } 8348 \text { ) } \\
\text { by the Lk group for } 21 \text { days }\end{array}$ & $\begin{array}{l}\text { Down-regulation of proinflammatory } \\
\text { mediator expression and } \\
\text { anti-inflammatory molecules, which } \\
\text { is improved causing an inductive } \\
\text { immune system and effector sites in } \\
\text { the mouse gut }\end{array}$ & [75] \\
\hline & & Dairy & Antioxidant effect & $\begin{array}{l}\text { The allocation of male rats }(\mathrm{n}= \\
\text { 24) into three groups, including } \\
\text { Group I (control) receiving mere } \\
\text { diet, Group II receiving diet plus } \\
5 \mathrm{~g} / \text { day of common dessert, and } \\
\text { Group III receiving diet plus } \\
5 \mathrm{~g} / \text { day of probiotic dessert }\end{array}$ & $\begin{array}{c}\text { The use of dairy dessert at a dose of } 5 \\
\text { g/day containing Lactobacillus } \\
\text { acidophilus La-5 at a dose of } 8 \text { log } \\
\text { CFU/g for } 15 \text { days }\end{array}$ & $\begin{array}{l}\text { The treatment caused a reduction in } \\
\text { serum lipid profiles by declining LDL, } \\
\text { total cholesterol and triacylglycerol }\end{array}$ & [76] \\
\hline & & Kefir & Cardioprotective effect & $\begin{array}{l}\text { The treatment of rats with } \\
\text { hypertension maintaining at a } \\
\text { temperature of } 22 \text { to } 23^{\circ} \mathrm{C} \text { and } \\
\text { 12/12-h light/dark cycle }\end{array}$ & $\begin{array}{l}\text { The daily use of kefir at a } \\
\text { concentration of } 0.3 \mathrm{~mL} / 100 \mathrm{~g} \mathrm{BW} \text { for } \\
60 \text { days }\end{array}$ & $\begin{array}{l}\text { The treatment with kefir caused a } \\
\text { reduction in the baroreflex sensitivity } \\
\text { and the cardiac autonomic control of } \\
\text { heart rate }\end{array}$ & [77] \\
\hline & & Kefir & Anti-obesity effect & $\begin{array}{l}\text { The allocation of mice aged a } \\
\text { month into four groups of eight } \\
\text { for eight weeks }\end{array}$ & $\begin{array}{l}\text { The use of kefir powder containing } \\
50 \mathrm{mg} / \mathrm{kg} \text { of polysaccharides, a yeast } \\
\text { cell at a density of } 102 \mathrm{cfu} / \mathrm{g} \text {, lactic } \\
\text { acid bacteria at a density of } 108 \mathrm{cfu} / \mathrm{g}\end{array}$ & $\begin{array}{l}\text { The treatment caused a reduction in } \\
\text { serum lipid profiles by declining LDL, } \\
\text { total cholesterol, and triacylglycerol }\end{array}$ & [78] \\
\hline & & Kefir & $\begin{array}{l}\text { Controlled endothelial } \\
\text { dysfunction }\end{array}$ & $\begin{array}{l}\text { The treatment of rats with } \\
\text { hypertension aged four months } \\
\text { maintaining at a temperature of } \\
22 \text { to } 23^{\circ} \mathrm{C} \text { and } 12 / 12-\mathrm{h} \\
\text { light/dark cycle }\end{array}$ & $\begin{array}{l}\text { The use of kefir at a concentration of } \\
0.3 \mathrm{~mL} / 100 \mathrm{~g} \mathrm{BW} \text { for two months }\end{array}$ & $\begin{array}{c}\text { The treatment caused a restoration of } \\
\text { intravascular NO availability as well } \\
\text { as an elevation of intravascular } \\
\text { ROS formation }\end{array}$ & [79] \\
\hline Non-dairy & $\begin{array}{l}\text { In animal } \\
\text { model }\end{array}$ & whey drinks & $\begin{array}{c}\text { Controlled } \\
\text { hypercholesterolaemia } \\
\text { damage }\end{array}$ & $\begin{array}{l}\text { Male Sprague-Dawley rats } \\
(\mathrm{n}=100) \text { kept at a temperature of } \\
23 \pm 2{ }^{\circ} \mathrm{C} \text {, humidity of } 55 \pm 5 \% \\
\text { and } 12: 12 \mathrm{~h} \text { light-dark cycle }\end{array}$ & $\begin{array}{l}\text { Administration of prebiotic } \\
\text { beverages for eight weeks }\end{array}$ & $\begin{array}{c}\text { Fructo oligosaccharides } \\
\text { (FOS)-enriched whey drink showed } \\
\text { beneficial health effects in the mice } \\
\text { with dyslipidemia via the reduction } \\
\text { of triacylglycerols (TAG) and low } \\
\text { density cholesterol (LDL) levels, and } \\
\text { the enhancement of the high density } \\
\text { cholesterol (HDL) level }\end{array}$ & [80] \\
\hline
\end{tabular}


Table 1. Cont.

\begin{tabular}{|c|c|c|c|c|c|c|c|}
\hline \multicolumn{8}{|c|}{ (c) } \\
\hline Beverage & Condition & Product & Activity & Subjects & Administration Time & Effect & Reference \\
\hline \multirow[t]{6}{*}{ Dairy } & $\begin{array}{l}\text { In human } \\
\text { model }\end{array}$ & Fermented milk & Controlled infection & Elderly patients $(\mathrm{n}=88)$ & $\begin{array}{l}\text { Daily administration of fermented } \\
\text { milk beverage once a day for six } \\
\text { months }\end{array}$ & $\begin{array}{l}\text { The elderly consumer of L. casei } \\
\text { strain Shirota (LcS) -fermented milk- } \\
\text { showed improved bowel movements } \\
\text { and lower incidence of fever }\end{array}$ & [81] \\
\hline & & Fermented milk & $\begin{array}{l}\text { In type } 2 \text { diabetes } \\
\text { subjects who are } \\
\text { boosted the glycemic } \\
\text { control, decrease } \\
\text { oxidative stress, and } \\
\text { also level of SCFA } \\
\text { is regulated }\end{array}$ & $\begin{array}{l}\text { Subjects with type } 2 \text { diabetes } \\
\text { mellitus }(n=50)\end{array}$ & $\begin{array}{l}\text { Daily administration of } 120 \mathrm{~g} / \mathrm{d} \\
\text { fermented milk for six weeks }\end{array}$ & $\begin{array}{l}\text { Reduce levels of } \mathrm{HbA} 1 \mathrm{c} \text { and } \\
\text { fructosamine, prevented } \\
\text { improvement of LDL-C and CT, and } \\
\text { reduction of } \\
\text { anti-inflammatory cytokines }\end{array}$ & [82] \\
\hline & & Fermented milk & $\begin{array}{l}\text { Controlled type II } \\
\text { diabetes }\end{array}$ & $\begin{array}{l}\text { Healthy subjects }(\mathrm{n}=17) \text { were } \\
\text { randomly allocated to two groups } \\
\text { of probiotics }(\mathrm{n}=8) \text { and control } \\
\qquad(\mathrm{n}=9)\end{array}$ & $\begin{array}{l}\text { Daily administration of } \\
\text { LcS-fermented milk drink two times } \\
\text { a day for four weeks by the } \\
\text { probiotic group }\end{array}$ & $\begin{array}{l}\text { Using up L. casei Shirota [LcS] } \\
\text { fermented milk drink impedes } \\
\text { high-fat diet-induced } \\
\text { insulin resistance }\end{array}$ & [83] \\
\hline & & Yogurt & $\begin{array}{l}\text { CRC survivors having } \\
\text { bowel symptoms have } \\
\text { been treated and this } \\
\text { led to improvement of } \\
\text { their life quality }\end{array}$ & $\begin{array}{l}\text { Research units in probiotic Group } \\
\qquad(\mathrm{n}=28)\end{array}$ & $\begin{array}{l}\text { Daily administration of probiotics } \\
(2 \times 109 \text { CFU/ml of L. rhamnosus } \\
\text { R0011 plus L. acidophilus R0052) two } \\
\text { times a day for } 12 \text { weeks }\end{array}$ & $\begin{array}{l}\text { Administration of probiotics } \\
\text { meaningfully reduced the percentage } \\
\text { of patients suffering from distressing } \\
\text { bowel symptom }\end{array}$ & [84] \\
\hline & & Yogurt & $\begin{array}{l}\text { The anti-inflammatory } \\
\text { activity }\end{array}$ & $\begin{array}{l}\text { Healthy obese and overweight } \\
\text { subjects }(n=75)\end{array}$ & $\begin{array}{l}\text { Daily administration of } 200 \mathrm{~g} / \text { day of } \\
\text { probiotic yoghurt }(108 \mathrm{CFU} / \mathrm{g} \text { of } \\
\text { L. acidophilus La5 plus Bifidobacterium } \\
\text { BB12, and L. casei DN001) for } 8 \text { weeks }\end{array}$ & $\begin{array}{c}\text { A reduction in production of } \\
\text { proinflammatory cytokines from } \\
\text { PBMCs and in serum hs-CRP levels } \\
\text { has been observed in overweight and } \\
\text { obese adults }\end{array}$ & [85] \\
\hline & & Yogurt & Anticancer effect & $\begin{array}{l}116 \text { males and } 173 \text { females } \\
\qquad(\mathrm{n}=289)\end{array}$ & $\begin{array}{l}\text { Different doses of } 0 \mathrm{~g} / \text { day (males and } \\
\text { females) in minimal tertile to } 85 \mathrm{~g} / \text { day } \\
\text { (males) and } 98 \mathrm{~g} / \text { day (females) in } \\
\text { maximal tertile for } 12 \text { years }\end{array}$ & $\begin{array}{l}\text { Administration of high-dose } \\
\text { supplemented yogurt reduced the } \\
\text { colorectal cancer, and stronger } \\
\text { protective effect was seen in the male } \\
\text { participants than in the females in the } \\
\text { European Prospective Investigation } \\
\text { into Cancer and Nutrition (EPIC) } \\
\text { cohort in Italy }\end{array}$ & [86] \\
\hline
\end{tabular}


Table 1. Cont.

\begin{tabular}{|c|c|c|c|c|c|c|c|}
\hline \multirow[b]{2}{*}{ Beverage } & \multicolumn{6}{|c|}{ (c) } & \multirow[b]{2}{*}{ Reference } \\
\hline & Condition & Product & Activity & Subjects & Administration Time & Effect & \\
\hline & & $\begin{array}{l}\text { Fermented dairy } \\
\text { product }\end{array}$ & $\begin{array}{l}\text { Shortened duration of } \\
\text { respiratory infections }\end{array}$ & $\begin{array}{l}\text { Randomly selected participants } \\
\text { with a median age of } 76(\mathrm{n}=1072)\end{array}$ & $\begin{array}{l}\text { Administration of } 200 \mathrm{~g} / \mathrm{d} \text { fermented } \\
\text { dairy product (intervention, } \mathrm{n}=537 \text { ) } \\
\text { or non-fermented dairy product } \\
\text { (control, } \mathrm{n}=535 \text { ) for three months, } \\
\text { and then one-month follow-up }\end{array}$ & $\begin{array}{l}\text { The duration of CID, especially URTI } \\
\text { and rhinopharyngitis, in elderly } \\
\text { subjects was shortened followed by } \\
\text { the administration of } L \text {. casei } \\
\text { DN-114001-containing fermented } \\
\text { dairy product }\end{array}$ & [87] \\
\hline Non-dairy & $\begin{array}{l}\text { In human } \\
\text { model }\end{array}$ & $\begin{array}{l}\text { Sugar-sweetened } \\
\text { beverages }\end{array}$ & Anti-obesity effect & $\begin{array}{l}\text { Obese and overweight } \\
\text { adolescents }(\mathrm{n}=224)\end{array}$ & $\begin{array}{l}\text { Daily administration }(12 \mathrm{oz}) \text { for } \\
\text { a year }\end{array}$ & $\begin{array}{l}\text { Reduced body mass index }(-0.57 \\
p=0.045) \text { and weight loss }(-1.9 \mathrm{~kg}, \\
p=0.04) \text { in the intervention groups } \\
\text { were significant when comparing } \\
\text { with the controls. }\end{array}$ & [88] \\
\hline
\end{tabular}


The dairy industry provides the most popular probiotic-containing beverages due to the effective transport of live probiotics [89-92], which can be associated with various health-promoting effects [93-104]. In a study by Cordeiro et al. [105] a mouse model of infection control caused by Salmonella typhimurium, showed that conventional fermented dairy beverages had a protective effect against pathogenic bacteria. Zhang et al. [106] reported antioxidant and gut microbiota regulating activities for the milk fermented by an enhanced probiotic system-containing Lactobacillus plantarum YW11. In some other studies, consumption of probiotic yogurt containing Bifidobacterium lactis Bb12 caused a significant decrease in Streptococcus mutans and Lactobacillus isolated from saliva in students with early stages of tooth decay [107]. In a study by Sunarti et al. [108], the use of probiotic-fermented goat milk kefir in rats with type II diabetes, reduced C-reactive protein, fasting glucose levels, HbA1C levels, and serum total cholesterol content [109]. In addition, positive effects have been reported on systemic oxidative stress, systemic inflammation, blood cell damage, and cognitive dysfunction following consumption of synbiotic-supplemented milk fermented with kefir grains [110]. In a study by Jalali et al. [111], the consumption of kefir has been associated with decreased cell proliferation and induction of apoptosis to control human acute erythroleukemia. Kefir administration has also been reported to have ex-vivo anti-inflammatory, anti-metabolic, and antiseptic effects as well as in vitro reduction of cell proliferation, migration and invasion of 4T1 cells [112]. Despite the reports of the positive effects of dairy-based probiotic drinks, they may affect consumer health, e.g., due to lactose malabsorption, allergy to milk proteins, high fat content, and cholesterol content. Therefore, non-dairy fermented beverages have been introduced as substitutes of probiotic dairy beverages in the food industry.

There are traditional non-dairy fermented drinks that are usually produced using fruit or vegetable juice as a main ingredient with many different health-beneficial effects [113-129].

Pomegranate juice fermented with probiotic L. plantarum ATCC 14,917 showed a higher total phenolic level and higher antioxidant activity [130]. In a study, Shalgam juice, which contains phenolic and microbial compounds, prevented the growth of Caco-2 cell lines [131]. Yan et al. [132] reported the cholesterol-lowering and antioxidant activity of probiotic fermented blueberry pomace in a mouse model. Łopusiewicz et al. [133] found a high antioxidant activity for kefir-like fermented beverage produced from flaxseed oil cake substrate. Xu et al. [134] reported the attenuation of early-phase after-meal (0-90 $\mathrm{min})$ insulin response by assuming probiotic fruit beverages and also that rose or bilberry juice assumed with the diet in the very early step after a meal (0-30 $\mathrm{min}$ ) lessened the insulin response and minimized insulin index compared to the control group due to their high phenolic contents. Results of a study recorded at temperatures above $150{ }^{\circ} \mathrm{C}$ allowed the observation of the highest antioxidant activity value of fermented grape pomace, which confirms that this activity is not directly related to the polyphenols content in pressurized hot water extraction [135]. Observed antioxidant and cytotoxic activity of Annona muricata L. (soursop) pulps and Rubus glaucus B. (blackberry) beverages, for human prostate carcinoma cells (PC3) and human cervix carcinoma cells (HeLa), are also another interesting example, since $\mathrm{IC}_{50}$ values like $0.8460 \pm 1.29$ and $7.1940 \pm 1.06$, have been reported, respectively [136].

\section{Conclusions}

Fermented foods account for about $25 \%$ of diets in Europe and $60 \%$ in developing countries [117]. In the meantime, these beverages have been reported among the most active functional foods. Overall health and disease prevention can be ensured by consuming functional beverages as desirable eating habits. Probiotic beverages as functional foods are currently a specialty in the field of selfcare and complementary proactive medicine. Both dairy and non-dairy beverages have a globalized demand for potential health benefits. Some drawbacks to such products can be overcome by new probiotic strains with the ability to grow and adapt to gastrointestinal conditions and high therapeutic ability by investigating various aspects of these products. Corbo et al. [18] indicated the main direction of functional beverages such as exploitation of microorganism functionality, optimization of the 
production and formulation of novel functional beverages, use of prebiotics and synbiotics, use and processing of natural ingredients, and the use of by-products of fruit and food industries to recover and use functional ingredients. The recent work of Rovinaru, and Pasarin, [137] remarked the importance of investigating the functionality of synbiotic microcapsules in protecting the survivability of probiotic cells during processing and storage and underlines challenges for synbiotic formulation in fruit beverages.

Despite the beneficial effect of probiotics on human health, they have shown certain complications, including development of genes related to antibiotic resistance, translocation to blood or tissues, spread of virulence factor in some strains, increased odds ratio of sepsis in preterm newborns and delayed colonization of some normal microflora [138]. In comparison with the probiotics, many studies reported useful efficiencies for postbiotics on host physiological parameters, including certain chemical structure, safety dose factors and prolonged shelf life $[139,140]$. The probiotics synthesize the postbiotics as non-viable or metabolic byproducts within the fermentation process, whose combination with other nutritional components can show health-promoting effects [141,142]. These compounds include organic acids, short chain fatty acids, endo-polysaccharides, exo-polysaccharides, peptides, cellular superficial proteins, plasmalogens, teichoic acids, muropeptides derived by peptidoglycan, and various enzymes.

As observed by Helkar et al. [143], the search for new functional food ingredients from natural sources and from by-products represent one of the most important challenges in food science and technology. Food industry by-products represent a valuable source of minerals, proteins, fatty acids, fibers, and bioactive substances, and they can constitute as an important raw material for the development of novel functional foods and beverages also. Recently several works remarked how the nanotechnologies open new triggering opportunities and challenges for functional foods development [144-146]. Particularly the current review of Durazzo et al. [147] gives an updated overview on nanoprebiotics and nanoprobiotics.

Grumezescu and Holban [148] presented the impact of novel technologies in nanoengineering on the design of improved and future beverages, with particular regards to nanoencapsulation, the use of metallic nanoparticles and/or nanofibers. Ozdal et al. [149] well described the role of encapsulation in functional beverages. For instance, Tamjidi et al. [150] indicate nanostructured lipid carriers containing hydrophobic nutraceuticals (astaxanthin-loaded nanostructured lipid carrier) have potential to be used for functional beverages/foods development.

At same time, considering how nowadays, consumers expect to be sure that a food product complies with its label and demand further information regarding the origin and sustainability of the product itself, it is of utmost importance to ensure both authenticity and traceability of beverages as recently outlined by Kamiloglu et al. [151].

Despite the many reports on the beneficial effects of probiotics on health, their effects on many diseases have not been fully investigated, and their mechanisms of action for promoting health and controlling disorders need further investigation. Among these, the dose-dependent effect of probiotics is a complex problem that needs to be resolved because short-term consumption of beverages has had a limited impact on the pathological process, and they have complex compounds, different levels of active ingredients, and poor standardization. Another problem is to consider appropriate controls for comparative analysis [152]. Accordingly, the effects of probiotics on health must be proven through the necessary protocols for a systematic method to probiotic evaluation. Pilot and serious screening and evaluation to achieve the positive therapeutic effects of a variety of dairy and non-dairy beverages can ultimately be investigated using cultured cell-based tests, followed by confirmation through in vitro and in vivo experiments and trials on animals and humans [153]. Nonetheless, some probiotic functions can be attributed to their antioxidant and anti-inflammatory activities. Several randomized controlled trials examined the safety and efficacy of probiotics to prevent and treat some clinical disorders, and a number of meta-analyses and systematic reviews evaluated the results of clinical trials on patients. As a result, there seems to exist a common agreement on the fact that probiotics can 
deliver their effects through the gastrointestinal tract and the immune system, and that their effects are interesting, as expected. The challenge of these beverages can be exploited further by adding active compounds in the view to possibly extend their beneficial health properties considering their easy use as it has been proposed also for foodstuff able to vehiculate micro nutrients in the view of a proactive medicine approach for prevention and therapy of health conditions [154] in a new, wider, and open area of research.

Author Contributions: A.N., A.D., and A.S. conceptualized, structured, reviewed, and supervised the present manuscript. A.N., E.B.S., M.L., S.B.S., A.D., and A.S. wrote, formatted, reviewed, and edited the manuscript. All authors made a substantial contribution to revising the work and approved it for publication. All authors have read and agreed to the published version of the manuscript.

Funding: The authors acknowledge the support of the research project: Nutraceutica come supporto nutrizionale nel paziente oncologico, CUP: B83D18000140007. E.B. Souto acknowledges the sponsorship of the projects M-ERA-NET-0004/2015-PAIRED and UIDB/04469/2020 (strategic fund), receiving support from the Portuguese Science and Technology Foundation, Ministry of Science and Education (FCT/MEC) through national funds, and co-financed by FEDER, under the Partnership Agreement PT2020.

Conflicts of Interest: The authors declare no conflict of interest.

\section{References}

1. Sanguansri, L.; Augustin, M.A. Microencapsulation in functional food product development. In Functional Food Product Development; Smith, J., Charter, E., Eds.; John Wiley and Sons: New York, NY, USA, 2010; pp. 3-23.

2. Ghoshal, G. Chapter 4-Beverages: A potential delivery system for nutraceuticals. Nutr. Beverages 2019, $12,1111-1142$.

3. Santini, A.; Novellino, E. Nutraceuticals: Beyond the diet before the drugs. Curr. Bioact. Compd. 2014, 10, 1-12. [CrossRef]

4. Andrew, R.; Izzo, A.A. Principles of pharmacological research of nutraceuticals. Br. J. Pharmacol. 2017, 174, 1177-1194. [CrossRef]

5. Santini, A.; Novellino, E. To nutraceuticals and back: Rethinking a concept. Foods 2017, 6, 74. [CrossRef] [PubMed]

6. Santini, A.; Tenore, G.C.; Novellino, E. Nutraceuticals: A paradigm of proactive medicine. Eur. J. Pharm. Sci. 2017, 96, 53-61. [CrossRef] [PubMed]

7. Abenavoli, L.; Izzo, A.A.; Milić, N.; Cicala, C.; Santini, A.; Capasso, R. Milk thistle (Silybum marianum): A concise overview on its chemistry, pharmacological, and nutraceutical uses in liver diseases. Phytother. Res. 2018, 32, 2202-2213. [CrossRef]

8. Daliu, P.; Santini, A.; Novellino, E. A decade of nutraceutical patents: Where are we now in 2018? Expert Opin. Ther. Pat. 2018, 28, 875-882. [CrossRef]

9. Durazzo, A.; D'Addezio, L.; Camilli, E.; Piccinelli, R.; Turrini, A.; Marletta, L.; Marconi, S.; Lucarini, M.; Lisciani, S.; Gabrielli, P.; et al. From plant compounds to botanicals and back: A current snapshot. Molecules 2018, 23, 1844. [CrossRef]

10. Durazzo, A. Extractable and non-extractable polyphenols: An overview. In Non-Extractable Polyphenols and Carotenoids: Importance in Human Nutrition and Health; Saura-Calixto, F., Pérez-Jiménez, J., Eds.; Royal Society of Chemistry: London, UK, 2018; pp. 1-37.

11. Durazzo, A.; Lucarini, M. A current shot and re-thinking of antioxidant research strategy. Braz. J. Anal. Chem. 2018, 5, 9-11. [CrossRef]

12. Santini, A.; Novellino, E. Nutraceuticals-shedding light on the grey area between pharmaceuticals and food. Expert Rev. Clin. Pharmacol. 2018, 11, 545-547. [CrossRef]

13. Santini, A.; Cammarata, S.M.; Capone, G.; Ianaro, A.; Tenore, G.C.; Pani, L.; Novellino, E. Nutraceuticals: Opening the debate for a regulatory framework. Br. J. Clin. Pharmacol. 2018, 84, 659-672. [CrossRef]

14. Daliu, P.; Santini, A.; Novellino, E. From pharmaceuticals to nutraceuticals: Bridging disease prevention and management. Expert Rev. Clin. Pharmacol. 2019, 12, 1-7. [CrossRef] 
15. Daliu, P.; Annunziata, G.; Tenore, G.C.; Santini, A. Abscisic acid identification in Okra, Abelmoschus esculentus L. (Moench): Perspective nutraceutical use for the treatment of diabetes. Nat. Prod. Res. 2019, 8, 1-7. [CrossRef]

16. Durazzo, A.; Lucarini, M. Extractable and non-extractable antioxidants. Molecules 2019, 24, 1933. [CrossRef] [PubMed]

17. Durazzo, A.; Lucarini, M.; Souto, E.B.; Cicala, C.; Caiazzo, E.; Izzo, A.A.; Novellino, E.; Santini, A. Polyphenols: A concise overview on the chemistry, occurrence and human health. Phytother. Res. 2019, 33, 2221-2243. [CrossRef] [PubMed]

18. Corbo, M.R.; Bevilacqua, A.; Petruzzi, L.; Casanova, F.P.; Sinigaglia, M. Functional beverages: The emerging side of functional foods commercial trends, research, and health implications. Compr. Rev. Food Sci. Food Saf. 2014, 13, 1192-1206. [CrossRef]

19. Tolun, A.; Altintas, Z. Medicinal properties and functional components of beverages. Funct. Med. Beverages 2019, 11, 2352-2384. [CrossRef]

20. Orrù, S.; Imperlini, E.; Nigro, E.; Alfieri, A.; Cevenini, A.; Polito, R.; Daniele, A.; Buono, P.; Mancini, A. Role of functional beverages on sport performance and recovery. Nutrients 2018, 10, 1470. [CrossRef]

21. Barbano, D.M. A 100-year review: The production of fluid (market) milk. J. Dairy Sci. 2017, 100, 9894-9902. [CrossRef]

22. Sun-Waterhouse, D. The development of fruit-based functional foods targeting the health and wellness market: A review. Int. J. Food Sci. Technol. 2011, 46, 899-920. [CrossRef]

23. Butu, M.; Rodino, S. 11-Fruit and vegetable-based beverages-Nutritional properties and health benefits. Nat. Beverages 2019, 13, 3033-3038.

24. Chandrasekara, A.; Shahidi, F. Herbal beverages: Bioactive compounds and their role in disease risk reduction-A review. J. Tradit. Complement. Med. 2018, 8, 451-458. [CrossRef] [PubMed]

25. Irkin, R. 14-Natural fermented beverages. In Natural Beverages; Grumezescu, A.M., Holban, A.M., Eds.; Academic Press: Cambridge, MA, USA, 2019; pp. 399-425. [CrossRef]

26. Misihairabgwi, J.; Cheikhyoussef, A. Traditional fermented foods and beverages of Namibia. J. Ethn. Foods 2017, 4, 145-153. [CrossRef]

27. Kaur, P.; Ghoshal, G.; Banerjee, U.C. 3-Traditional bio-preservation in beverages: Fermented beverages. In Preservatives and Preservation Approaches in Beverages; Grumezescu, A.M., Holban, A.M., Eds.; Academic Press: Cambridge, MA, USA, 2019; pp. 69-113. [CrossRef]

28. Taylor, J.R.N. Fermentation: Foods and nonalcoholic beverages. In Encyclopedia of Food Grains 2016; Istrati, D., Pricop, E., Georgiana, P., Vizireanu, C., Eds.; Elsevier: Amsterdam, The Netherlands, 2016; Volume 3, pp. 183-192.

29. Li, S.; Shahidi, F.; Ho, C.-T. Chemistry of functional beverages. In Handbook of Functional Beverages and Human Health; Shahidi, F., Alasalvar, C., Eds.; CRC Press: Oxfordshire, UK, 2016.

30. Vijaya Kumar, B.; Vijayendra, S.V.; Reddy, O.V. Trends in dairy and non-dairy probiotic products-A review. J. Food Sci. Technol. 2015, 52, 6112-6124. [CrossRef] [PubMed]

31. Llamas-Arriba, M.G.; Hernández-Alcántara, A.M.; Yépez, A.; Aznar, R.; Dueñas, M.T.; López, P. 12-Functional and nutritious beverages produced by lactic acid bacteria. In Nutrients in Beverages; Grumezescu, A.M., Holban, A.M., Eds.; Academic Press: Cambridge, MA, USA, 2019; pp. 419-465. [CrossRef]

32. Shori, A.B. Influence of food matrix on the viability of probiotic bacteria: A review based on dairy and non-dairy beverages. Food Biosci. 2016, 13, 1-8. [CrossRef]

33. Kandylis, P.; Pissaridi, K.; Bekatorou, A.; Kanellaki, M.; Koutinas, A.A. Dairy and non-dairy probiotic beverages. Curr. Opin. Food Sci. 2016, 7, 58-63. [CrossRef]

34. Makinen, O.E.; Wanhalinna, V.; Zannini, E.; Arendt, E.K. Foods for special dietary needs: Non-dairy plant-based milk substitutes and fermented dairy-type products. Crit. Rev. Food Sci. Nutr. 2016, 56, 339-349. [CrossRef] [PubMed]

35. Ranadheera, S.C.; Vidanarachchi, K.J.; Rocha, S.R.; Cruz, G.A.; Ajlouni, S. Probiotic delivery through fermentation: Dairy vs. non-dairy beverages. Fermentation 2017, 3. [CrossRef]

36. Ranadheera, C.S.; Prasanna, P.H.P.; Pimentel, T.C.; Azeredo, D.R.P.; Rocha, R.S.; Cruz, A.G.; Vidanarachchi, J.K.; Naumovski, N.; McConchie, R.; Ajlouni, S.; et al. 6-Microbial safety of nonalcoholic beverages. In Safety Issues in Beverage Production; Grumezescu, A.M., Holban, A.M., Eds.; Academic Press: Cambridge, MA, USA, 2020; pp. 187-221. [CrossRef] 
37. Mielby, L.A.; Wang, Q.J.; Jensen, S.; Sjoerup Bertelsen, A.; Kidmose, U.; Spence, C.; Byrne, D.V. See, feel, taste: The influence of receptacle colour and weight on the evaluation of flavoured carbonated beverages. Foods 2018, 7, 119. [CrossRef]

38. Davani-Davari, D.; Negahdaripour, M.; Karimzadeh, I.; Seifan, M.; Mohkam, M.; Masoumi, S.J.; Berenjian, A.; Ghasemi, Y. Prebiotics: Definition, types, sources, mechanisms, and clinical applications. Foods 2019, 8, 92. [CrossRef]

39. Schoina, V.; Terpou, A.; Papadaki, A.; Bosnea, L.; Kopsahelis, N.; Kanellaki, M. Enhanced aromatic profile and functionality of cheese whey beverages by incorporation of probiotic cells immobilized on pistacia terebinthus resin. Foods 2020, 9, 13. [CrossRef] [PubMed]

40. Mustafa, S.M.; Chua, L.S. 13-Green technological fermentation for probioticated beverages for health enhancement. In Biotechnological Progress and Beverage Consumption; Grumezescu, A.M., Holban, A.M., Eds.; Academic Press: Cambridge, MA, USA, 2020; pp. 407-434. [CrossRef]

41. Mota de Carvalho, N.; Costa, M.E.; Silva, S.; Pimentel, L.; Fernandes, H.T.; Pintado, E.M. Fermented foods and beverages in human diet and their influence on gut microbiota and health. Fermentation 2018, 4. [CrossRef]

42. Chilton, N.S.; Burton, P.J.; Reid, G. Inclusion of fermented foods in food guides around the world. Nutrition 2015, 7. [CrossRef] [PubMed]

43. Mokoena, M.P.; Mutanda, T.; Olaniran, A.O. Perspectives on the probiotic potential of lactic acid bacteria from African traditional fermented foods and beverages. Food Nutr. Res. 2016, 60, 29630. [CrossRef]

44. Baschali, A.; Tsakalidou, E.; Kyriacou, A.; Karavasiloglou, N.; Matalas, A.L. Traditional low-alcoholic and non-alcoholic fermented beverages consumed in European countries: A neglected food group. Nutr. Res. Rev. 2017, 30, 1-24. [CrossRef]

45. Raghuwanshi, S.; Misra, S.; Sharma, R.; Bisen, P. Probiotics: Nutritional therapeutic tool. J. Probiotics Health 2018, 6, 194. [CrossRef]

46. Valls, J.; Pasamontes, N.; Pantaleón, A.; Vinaixa, S.; Vaqué, M.; Soler, A.; Millán, S.; Gómez, X. Prospects of functional foods/nutraceuticals and markets. In Natural Products; Ramawat, K.G., Mérillon, J.-M., Eds.; Springer: Berlin/Heidelberg, Germany, 2013; pp. 2491-2525. [CrossRef]

47. The Europe Probiotic Market is Expected to Reach $\$ 616.13$ Million by 2018, at a CAGR of 7.7\% from 2013 to 2018. 2018. Available online: https://www.prnewswire.com/news-releases/the-europe-probiotic-market-isexpected-to-reach-61613-million-by-2018-at-a-cagr-of-77-from-2013-to-2018-286204451.html (accessed on 11 December 2019).

48. Tesfaye, W.; Suarez-Lepe, J.A.; Loira, I.; Palomero, F.; Morata, A. 14-Dairy and nondairy-based beverages as a vehicle for probiotics, prebiotics, and synbiotics: Alternatives to health versus disease binomial approach through food. In Milk-Based Beverages; Grumezescu, A.M., Holban, A.M., Eds.; Woodhead Publishing: Cambridge, UK, 2019; pp. 473-520. [CrossRef]

49. Yadav, R.; Puniya, A.K.; Shukla, P. Probiotic properties of lactobacillus plantarum RYPR1 from an indigenous fermented beverage raabadi. Front. Microbiol. 2016, 7, 1683. [CrossRef]

50. Silva, M.S.; Ramos, C.L.; González-Avila, M.; Gschaedler, A.; Arrizon, J.; Schwan, R.F.; Dias, D.R. Probiotic properties of weissella cibaria and leuconostoc citreum isolated from tejuino-A typical Mexican beverage. LWT 2017, 86, 227-232. [CrossRef]

51. Tamang, J.P.; Shin, D.-H.; Jung, S.-J.; Chae, S.W. Functional properties of microorganisms in fermented foods. Front. Microbiol. 2016, 7, 578. [CrossRef]

52. Tamang, J.P.; Watanabe, K.; Holzapfel, W.H. Review: Diversity of microorganisms in global fermented foods and beverages. Front. Microbiol. 2016, 7, 377. [CrossRef]

53. Hill, C.; Guarner, F.; Reid, G.; Gibson, G.R.; Merenstein, D.J.; Pot, B.; Morelli, L.; Canani, R.B.; Flint, H.J.; Salminen, S.; et al. The international scientific association for probiotics and prebiotics consensus statement on the scope and appropriate use of the term probiotic. Nat. Rev. Gastroenterol. Hepatol. 2014, 11, 506-514. [CrossRef]

54. Blatchford, P.; Ansell, J.; Godoy, M.; Fahey, G.; Garcia-Mazcorro, J.; Gibson, G.R.; Goh, Y.; Hotchkiss, A.; Hutkins, R.; Lacroix, C.; et al. Prebiotic mechanisms, functions and applications-A review. Int. J. Probiotics Prebiotics 2013, 8, 109-132.

55. Rioux, K.P.; Madsen, K.L.; Fedorak, R.N. The role of enteric microflora in inflammatory bowel disease: Human and animal studies with probiotics and prebiotics. Gastroenterol. Clin. N. Am. 2005, 34, 465-482. [CrossRef] [PubMed] 
56. Nigam, D. Probiotics as functional foods in enhancing gut immunity. In Functional Food and Human Health; Rani, V., Yadav, U.C.S., Eds.; Springer: Singapore, 2018.

57. Yadav, R.; Shukla, P. Probiotics for human health: Current progress and applications. In Recent Advances in Applied Microbiology; Shukla, P., Ed.; Springer: Singapore, 2017.

58. Bhardwaj, R.; Singh, B.P.; Sandhu, N.; Singh, N.; Kaur, R.; Rokana, N.; Singh, K.S.; Chaudhary, V.; Panwar, H. Probiotic mediated NF- $\mathrm{KB}$ regulation for prospective management of type 2 diabetes. Mol. Bio. Rep. 2020, 47, 2301-2313. [CrossRef] [PubMed]

59. Hati, S.; Das, S.; Mandal, S. 4-Technological advancement of functional fermented dairy beverages. In Engineering Tools in the Beverage Industry; Grumezescu, A.M., Holban, A.M., Eds.; Woodhead Publishing: Cambridge, UK, 2019; pp. 101-136. [CrossRef]

60. Sabokbar, N.; Khodaiyan, F. Total phenolic content and antioxidant activities of pomegranate juice and whey based novel beverage fermented by kefir grains. J. Food Sci. Technol. 2016, 53, 739-747. [CrossRef] [PubMed]

61. Park, H.; Lee, M.; Kim, K.T.; Park, E.; Paik, H.D. Antioxidant and antigenotoxic effect of dairy products supplemented with red ginseng extract. J. Dairy Sci. 2018, 101, 8702-8710. [CrossRef]

62. Likotrafiti, E.; Valavani, P.; Argiriou, A.; Rhoades, J. In vitro evaluation of potential antimicrobial synbiotics using Lactobacillus kefiri isolated from kefir grains. Int. Dairy J. 2015, 45, 23-30. [CrossRef]

63. Haghshenas, B.; Nami, Y.; Haghshenas, M.; Abdullah, N.; Rosli, R.; Radiah, D.; Yari, A. Bioactivity characterization of Lactobacillus strains isolated from dairy products. Microbiologyopen 2015, 4. [CrossRef]

64. Baba, A.S.; Najarian, A.; Shori, A.B.; Lit, K.W.; Keng, G.A. Viability of lactic acid bacteria, antioxidant activity and in vitro inhibition of angiotensin-I-converting enzyme of lycium barbarum yogurt. Arab. J. Sci. Eng. 2014, 39, 5355-5362. [CrossRef]

65. Iraporda, C.; Romanin, D.E.; Rumbo, M.; Garrote, G.L.; Abraham, A.G. The role of lactate on the immunomodulatory properties of the nonbacterial fraction of kefir. Food Res. Int. 2014, 62, 247-253. [CrossRef]

66. Chen, R.; Chen, W.; Chen, H.; Zhang, G.; Chen, W. Comparative Evaluation of the Antioxidant Capacities, Organic Acids, and Volatiles of Papaya Juices Fermented by Lactobacillus acidophilus and Lactobacillus plantarum. J. Food Qual. 2018, 1-12. [CrossRef]

67. Gonzalez-Larena, M.; Garcia-Llatas, G.; Clemente, G.; Barbera, R.; Lagarda, M.J. Plant sterol oxides in functional beverages: Influence of matrix and storage. Food Chem. 2015, 173, 881-889. [CrossRef] [PubMed]

68. Amorim, J.C.; Piccoli, R.H.; Duarte, W.F. Probiotic potential of yeasts isolated from pineapple and their use in the elaboration of potentially functional fermented beverages. Food Res. Int. 2018, 107, 518-527. [CrossRef] [PubMed]

69. Freire, A.L.; Ramos, C.L.; Schwan, R.F. Effect of symbiotic interaction between a fructooligosaccharide and probiotic on the kinetic fermentation and chemical profile of maize blended rice beverages. Food Res. Int. 2017, 100, 698-707. [CrossRef] [PubMed]

70. Liu, Y.; Song, X.; Zhang, D.; Zhou, F.; Wang, D.; Wei, Y.; Gao, F.; Xie, L.; Jia, G.; Wu, W.; et al. Blueberry anthocyanins: Protection against ageing and light-induced damage in retinal pigment epithelial cells. Br. J. Nutr. 2012, 108, 16-27. [CrossRef]

71. Wu, C.; Li, T.; Qi, J.; Jiang, T.; Xu, H.; Lei, H. Effects of lactic acid fermentation-based biotransformation on phenolic profiles, antioxidant capacity and flavor volatiles of apple juice. LWT 2020, 122, 109064. [CrossRef]

72. Ethiraj, S.; Vaithilingam, M.; Chandrasekaran, S.; Mehra, A.; Prakash, S.; Agarwal, A. Fermentation of beet juice using lactic acid bacteria and its cytotoxic activity against human liver cancer cell lines HepG2. Curr. Bioact. Compd. 2016, 12. [CrossRef]

73. Cholakov, R.; Tumbarski, Y.; Yanakieva, V.; Dobrev, I.; Salim, Y.; Denkova, Z. Antimicrobial activity of Leuconostoc lactis strain BT17, isolated from a spontaneously fermented cereal beverage (Boza). J. Microbiol. Biotech. Food Sci. 2017, 7, 47-49. [CrossRef]

74. Hamet, M.F.; Medrano, M.; Perez, P.F.; Abraham, A.G. Oral administration of kefiran exerts a bifidogenic effect on BALB/c mice intestinal microbiota. Benef. Microbes 2016, 7, 237-246. [CrossRef]

75. Carasi, P.; Racedo, S.M.; Jacquot, C.; Romanin, D.E.; Serradell, M.A.; Urdaci, M.C. Impact of kefir derived Lactobacillus kefiri on the mucosal immune response and gut microbiota. J. Immunol. Res. 2015, 2015, 361604. [CrossRef] 
76. Moura, C.S.; Lollo, P.C.B.; Morato, P.N.; Esmerino, E.A.; Margalho, L.P.; Santos-Junior, V.A.; Coimbra, P.T.; Cappato, L.P.; Silva, M.C.; Garcia-Gomes, A.S.; et al. Assessment of antioxidant activity, lipid profile, general biochemical and immune system responses of Wistar rats fed with dairy dessert containing Lactobacillus acidophilus La-5. Food Res. Int. 2016, 90, 275-280. [CrossRef] [PubMed]

77. Klippel, B.F.; Duemke, L.B.; Leal, M.A.; Friques, A.G.; Dantas, E.M.; Dalvi, R.F.; Gava, A.L.; Pereira, T.M.; Andrade, T.U.; Meyrelles, S.S.; et al. Effects of kefir on the cardiac autonomic tones and baroreflex sensitivity in spontaneously hypertensive rats. Front. Physiol. 2016, 7, 211. [CrossRef] [PubMed]

78. Choi, J.-W.; Kang, H.W.; Lim, W.-C.; Kim, M.-K.; Lee, I.-Y.; Cho, H.-Y. Kefir prevented excess fat accumulation in diet-induced obese mice. Biosci. Biotechnol. Biochem. 2017, 81, 958-965. [CrossRef] [PubMed]

79. Friques, A.G.F.; Arpini, C.M.; Kalil, I.C.; Gava, A.L.; Leal, M.A.; Porto, M.L.; Nogueira, B.V.; Dias, A.T.; Andrade, T.U.; Pereira, T.M.C.; et al. Chronic administration of the probiotic kefir improves the endothelial function in spontaneously hypertensive rats. J. Transl. Med. 2015, 13, 390. [CrossRef] [PubMed]

80. Yasmin, A.; Butt, M.S.; van Baak, M.; Shahid, M.Z. Supplementation of prebiotics to a whey-based beverage reduces the risk of hypercholesterolaemia in rats. Int. Dairy J. 2015, 48, 80-84. [CrossRef]

81. Nagata, S.; Asahara, T.; Wang, C.; Suyama, Y.; Chonan, O.; Takano, K.; Daibou, M.; Takahashi, T.; Nomoto, K.; Yamashiro, Y.; et al. The effectiveness of lactobacillus beverages in controlling infections among the residents of an aged care facility: A randomized placebo-controlled double-blind trial. Ann. Nutr. Metab. 2016, 68, 51-59. [CrossRef]

82. Tonucci, L.B.; Olbrich Dos Santos, K.M.; Licursi de Oliveira, L.; Rocha Ribeiro, S.M.; Duarte Martino, H.S. Clinical application of probiotics in type 2 diabetes mellitus: A randomized, double-blind, placebo-controlled study. Clin. Nutr. 2017, 36, 85-92. [CrossRef]

83. Hulston, C.J.; Churnside, A.A.; Venables, M.C. Probiotic supplementation prevents high-fat, overfeeding-induced insulin resistance in human subjects. Br. J. Nutr. 2015, 113, 596-602. [CrossRef]

84. Lee, J.Y.; Chu, S.H.; Jeon, J.Y.; Lee, M.K.; Park, J.H.; Lee, D.C.; Lee, J.W.; Kim, N.K. Effects of 12 weeks of probiotic supplementation on quality of life in colorectal cancer survivors: A double-blind, randomized, placebo-controlled trial. Dig. Liver Dis. 2014, 46, 1126-1132. [CrossRef]

85. Zarrati, M.; Salehi, E.; Nourijelyani, K.; Mofid, V.; Zadeh, M.J.; Najafi, F.; Ghaflati, Z.; Bidad, K.; Chamari, M.; Karimi, M.; et al. Effects of probiotic yogurt on fat distribution and gene expression of proinflammatory factors in peripheral blood mononuclear cells in overweight and obese people with or without weight-loss diet. J. Am. Coll. Nutr. 2014, 33, 417-425. [CrossRef]

86. Pala, V.; Sieri, S.; Berrino, F.; Vineis, P.; Sacerdote, C.; Palli, D.; Masala, G.; Panico, S.; Mattiello, A.; Tumino, R.; et al. Yogurt consumption and risk of colorectal cancer in the Italian European prospective investigation into cancer and nutrition cohort. Int. J. Cancer 2011, 129, 2712-2719. [CrossRef] [PubMed]

87. Guillemard, E.; Tondu, F.; Lacoin, F.; Schrezenmeir, J. Consumption of a fermented dairy product containing the probiotic Lactobacillus casei DN-114001 reduces the duration of respiratory infections in the elderly in a randomised controlled trial. Br. J. Nutr. 2010, 103, 58-68. [CrossRef] [PubMed]

88. Ebbeling, C.B.; Feldman, H.A.; Chomitz, V.R.; Antonelli, T.A.; Gortmaker, S.L.; Osganian, S.K.; Ludwig, D.S. A randomized trial of sugar-sweetened beverages and adolescent body weight. N. Engl. J. Med. 2012, 367, 1407-1416. [CrossRef] [PubMed]

89. Rodríguez-Pérez, C.; Pimentel-Moral, S.; Ochando-Pulido, J. 4-New trends and perspectives in functional dairy-based beverages. In Milk-Based Beverages; Grumezescu, A.M., Holban, A.M., Eds.; Woodhead Publishing: Cambridge, UK, 2019; pp. 95-138. [CrossRef]

90. Üstün-Aytekin, Ö.; Şeker, A.; Arısoy, S. The effect of in vitro gastrointestinal simulation on bioactivities of kefir. Int. J. Food Sci. Technol. 2020, 55, 283-292. [CrossRef]

91. Akal, C.; Turkmen, N.; Özer, B. 10-Technology of dairy-based beverages. In Milk-Based Beverages; Grumezescu, A.M., Holban, A.M., Eds.; Woodhead Publishing: Cambridge, UK, 2019; pp. 331-372. [CrossRef]

92. Turkmen, N.; Akal, C.; Özer, B. Probiotic dairy-based beverages: A review. J. Funct. Foods 2019, 53, 62-75. [CrossRef]

93. Van Wyk, J. 12-Kefir: The champagne of fermented beverages. In Fermented Beverages; Grumezescu, A.M., Holban, A.M., Eds.; Woodhead Publishing: Cambridge, UK, 2019; pp. 437-527. [CrossRef] 
94. Shori, A.B.; Baba, A.S.; Muniandy, P. 5-Potential health-promoting effects of probiotics in dairy beverages. In Value-Added Ingredients and Enrichments of Beverages; Grumezescu, A.M., Holban, A.M., Eds.; Academic Press: Cambridge, MA, USA, 2019; pp. 173-204. [CrossRef]

95. Magno, M.B.; Nadelman, P.; de Abreu Brandi, T.C.; Pithon, M.M.; Fonseca-Gonçalves, A.; da Cruz, A.G.; Maia, L.C. 15-The effect of dairy probiotic beverages on oral health. In Milk-Based Beverages; Grumezescu, A.M., Holban, A.M., Eds.; Woodhead Publishing: Cambridge, UK, 2019; pp. 521-556. [CrossRef]

96. Grom, L.C.; Rocha, R.S.; Balthazar, C.F.; Guimarães, J.T.; Coutinho, N.M.; Barros, C.P.; Pimentel, T.C.; Venâncio, E.L.; Collopy Junior, I.; Maciel, P.M.C.; et al. Postprandial glycemia in healthy subjects: Which probiotic dairy food is more adequate? J. Dairy Sci. 2020, 103, 1110-1119. [CrossRef]

97. Zoumpopoulou, G.; Pot, B.; Tsakalidou, E.; Papadimitriou, K. Dairy probiotics: Beyond the role of promoting gut and immune health. Int. Dairy J. 2017, 67, 46-60. [CrossRef]

98. Bourrie, B.C.T.; Willing, B.P.; Cotter, P.D. The microbiota and health promoting characteristics of the fermented beverage kefir. Front. Microbiol. 2016, 7, 647. [CrossRef]

99. Shida, K.; Sato, T.; Iizuka, R.; Hoshi, R.; Watanabe, O.; Igarashi, T.; Miyazaki, K.; Nanno, M.; Ishikawa, F. Daily intake of fermented milk with Lactobacillus casei strain Shirota reduces the incidence and duration of upper respiratory tract infections in healthy middle-aged office workers. Eur. J. Nutr. 2017, 56, 45-53. [CrossRef]

100. Rizzoli, R.; Biver, E. Effects of fermented milk products on bone. Calcif. Tissue Int. 2018, 102, 489-500. [CrossRef]

101. Sharifi, M.; Moridnia, A.; Mortazavi, D.; Salehi, M.; Bagheri, M.; Sheikhi, A. Kefir: A powerful probiotics with anticancer properties. Med. Oncol. 2017, 34, 183. [CrossRef] [PubMed]

102. Ma'mon, M.H.; Nuirat, A.; Zihlif, M.A.; Taha, M.O. Exploring the influence of culture conditions on kefir's anticancer properties. J. Dairy Sci. 2018, 101, 3771-3777.

103. Ayyash, M.; Al-Dhaheri, A.S.; Al Mahadin, S.; Kizhakkayil, J.; Abushelaibi, A. In vitro investigation of anticancer, antihypertensive, antidiabetic, and antioxidant activities of camel milk fermented with camel milk probiotic: A comparative study with fermented bovine milk. J. Dairy Sci. 2018, 101, 900-911. [CrossRef] [PubMed]

104. Raikos, V.; Ni, H.; Hayes, H.; Ranawana, V. Antioxidant properties of a yogurt beverage enriched with salal (gaultheria shallon) berries and blackcurrant (ribes nigrum) pomace during cold storage. Beverages 2018, 5, 2. [CrossRef]

105. Cordeiro, M.A.; Souza, E.L.S.; Arantes, R.M.E.; Balthazar, C.F.; Guimaraes, J.T.; Scudino, H.; Silva, H.L.A.; Rocha, R.S.; Freitas, M.Q.; Esmerino, E.A.; et al. Fermented whey dairy beverage offers protection against Salmonella enterica ssp. enterica serovar Typhimurium infection in mice. J. Dairy Sci. 2019, 102, 6756-6765. [CrossRef] [PubMed]

106. Zhang, J.; Zhao, X.; Jiang, Y.; Zhao, W.; Guo, T.; Cao, Y.; Teng, J.; Hao, X.; Zhao, J.; Yang, Z.; et al. Antioxidant status and gut microbiota change in an aging mouse model as influenced by exopolysaccharide produced by Lactobacillus plantarum YW11 isolated from Tibetan kefir. J. Dairy Sci. 2017, 100, 6025-6041. [CrossRef]

107. Javid, A.Z.; Amerian, E.; Basir, L.; Ekrami, A.; Haghighizadeh, M.H.; Maghsoumi-Norouzabad, L. Effects of the consumption of probiotic yogurt containing bifidobacterium lactis Bb12 on the levels of streptococcus mutans and lactobacilli in saliva of students with initial stages of dental caries: A double-blind randomized controlled trial. Caries Res. 2020, 54, 68-74.

108. Tyas, A.S.A.; Kristian, S.D. The influence of goat milk and soybean milk kefir on IL-6 and crp levels in diabetic rats. Rom. J. Diabetes Nutr. Metab. Dis. 2015, 22, 261-267.

109. Ostadrahimi, A.; Taghizadeh, A.; Mobasseri, M.; Farrin, N.; Payahoo, L.; Beyramalipoor Gheshlaghi, Z.; Vahedjabbari, M. Effect of probiotic fermented milk (kefir) on glycemic control and lipid profile in type 2 diabetic patients: A randomized double-blind placebo-controlled clinical trial. Iran J. Public Health 2015, 44, 228-237. [PubMed]

110. Ton, A.; Campagnaro, B.; Alves, G.; Aires, R.; Côco, L.; Arpini, C.; Oliveira, T.; Campos-Toimil, M.; Meyrelles, S.; Pereira, T.; et al. Oxidative stress and dementia in alzheimer's patients: Effects of synbiotic supplementation. Oxid. Med. Cell Longev. 2020, 2020, 1-14. [CrossRef]

111. Jalali, F.; Sharifi, M.; Salehi, R. Kefir induces apoptosis and inhibits cell proliferation in human acute erythroleukemia. Med. Oncol. 2016, 33, 7. [CrossRef] [PubMed] 
112. Zamberi, N.R.; Abu, N.; Mohamed, N.E.; Nordin, N.; Keong, Y.S.; Beh, B.K.; Zakaria, Z.A.; Nik Abdul Rahman, N.M.; Alitheen, N.B. The antimetastatic and antiangiogenesis effects of kefir water on murine breast cancer cells. Integr. Cancer Ther. 2016, 15, 53-66. [CrossRef] [PubMed]

113. Yang, F.; Song, J.; Liang, M.; Ma, F.; Mao, X.; Ma, C.; Zhang, W.; Huang, Z. Overview of beverages with anti-aging functions in Chinese market. Rejuvenation Res. 2014, 17, 197-200. [CrossRef] [PubMed]

114. Gawkowski, D.; Chikindas, M.L. Non-dairy probiotic beverages: The next step into human health. Benef. Microbes 2013, 4, 127-142. [CrossRef] [PubMed]

115. Roselló-Soto, E.; Garcia, C.; Fessard, A.; Barba, J.F.; Munekata, E.S.P.; Lorenzo, M.J.; Remize, F. Nutritional and microbiological quality of tiger nut tubers (cyperus esculentus), derived plant-based and lactic fermented beverages. Fermentation 2018, 5, 3. [CrossRef]

116. Khezri, S.; Dehghan, P.; Mahmoudi, R.; Jafarlou, M. Fig juice fermented with lactic acid bacteria as a nutraceutical product. Pharm. Sci. 2016, 22, 260-266. [CrossRef]

117. Bansal, S.; Mangal, M.; Sharma, S.K.; Gupta, R.K. Non-dairy Based Probiotics: A healthy treat for intestine. Crit. Rev. Food Sci. Nutr. 2016, 56, 1856-1867. [CrossRef]

118. Singh, D.; Vij, S.; Singh, B.P. Antioxidative and antimicrobial activity of whey based fermented soy beverage with curcumin supplementation. Indian J. Dairy Sci. 2016, 69, 171-177.

119. Fernandes Pereira, A.L.; Rodrigues, S. Chapter 15-Turning fruit juice into probiotic beverages. In Fruit Juices; Rajauria, G., Tiwari, B.K., Eds.; Academic Press: San Diego, CA, USA, 2018; pp. 279-287. [CrossRef]

120. Mantzourani, I.; Nouska, C.; Terpou, A.; Alexopoulos, A.; Bezirtzoglou, E.; Panayiotidis, M.I.; Galanis, A.; Plessas, S. Production of a novel functional fruit beverage consisting of cornelian cherry juice and probiotic bacteria. Antioxidants 2018, 7. [CrossRef]

121. Dey, G. Non-dairy Probiotic Foods: Innovations and Market Trends. In Innovations in Technologies for Fermented Food and Beverage Industries; Panda, S., Shetty, P., Eds.; Springer, Cham: Basel, Switzerland, 2018; pp. 159-173.

122. Patel, A. Probiotic fruit and vegetable juices- recent advances and future perspective. Int. Food Res. J. 2017, 24, 1850-1857.

123. De Oliveira Ribeiro, A.P.; Gomes, F.D.S.; Maria Olbrich dos Santos, K.; da Matta, V.M.; Freitas de Sá, D.D.G.C.; Santiago, M.C.P.D.A.; Conte, C.; de Oliveira Costa, S.D.; Oliveira Ribeiro, L.D.; de Oliveira Godoy, R.L.; et al. Development of a probiotic non-fermented blend beverage with juçara fruit: Effect of the matrix on probiotic viability and survival to the gastrointestinal tract. LWT Food Sci. Technol. 2020, 118, 108756. [CrossRef]

124. Giri, S.S.; Sukumaran, V.; Sen, S.S.; Park, S.C. Use of a potential probiotic, lactobacillus casei L4, in the preparation of fermented coconut water beverage. Front. Microbiol. 2018, 9, 1976. [CrossRef] [PubMed]

125. Deswal, A. Non-dairy based beverages: An insight. J. Nutr. Food Res. Technol. 2018, 1, 1-4.

126. Pimentel, T.C.; Klososki, S.J.; Rosset, M.; Barão, C.E.; Marcolino, V.A. 14-Fruit juices as probiotic foods. In Sports and Energy Drinks; Grumezescu, A.M., Holban, A.M., Eds.; Woodhead Publishing: Cambridge, UK; Elsevier: Amsterdam, The Netherlands, 2019; pp. 483-513. [CrossRef]

127. Camargo Prado, F.; De Dea Lindner, J.; Inaba, J.; Thomaz-Soccol, V.; Kaur Brar, S.; Soccol, C.R. Development and evaluation of a fermented coconut water beverage with potential health benefits. J. Funct. Foods 2015, 12, 489-497. [CrossRef]

128. Panghal, A.; Janghu, S.; Virkar, K.; Gat, Y.; Kumar, V.; Chhikara, N. Potential non-dairy probiotic products-A healthy approach. Food Biosci. 2018, 21, 80-89. [CrossRef]

129. Fessard, A.; Kapoor, A.; Patche, J.; Assemat, S.; Hoarau, M.; Bourdon, E.; Bahorun, T.; Remize, F. Lactic fermentation as an efficient tool to enhance the antioxidant activity of tropical fruit juices and teas. Microorganisms 2017. [CrossRef] [PubMed]

130. Mantzourani, I.; Kazakos, S.; Terpou, A.; Alexopoulos, A.; Bezirtzoglou, E.; Bekatorou, A.; Plessas, S. Potential of the probiotic lactobacillus plantarum ATCC 14917 strain to produce functional fermented pomegranate juice. Foods 2018, 8, 4. [CrossRef]

131. Ekinci, F.Y.; Baser, G.M.; Özcan, E.; Üstündağ, Ö.G.; Korachi, M.; Sofu, A.; Blumberg, J.B.; Chen, C.Y.O. Characterization of chemical, biological, and antiproliferative properties of fermented black carrot juice, shalgam. Eur. Food Res. Technol. 2016, 242, 1355-1368. [CrossRef]

132. Yan, Y.; Zhang, F.; Chai, Z.; Liu, M.; Battino, M.; Meng, X. Mixed fermentation of blueberry pomace with L. rhamnosus GG and L. plantarum-1: Enhance the active ingredient, antioxidant activity and health-promoting benefits. Food Chem. Toxicol. 2019, 131, 110541. [CrossRef] 
133. Łopusiewicz, Ł.; Drozłowska, E.; Siedlecka, P.; Mężyńska, M.; Bartkowiak, A.; Sienkiewicz, M.; Zielińska-Bliźniewska, H.; Kwiatkowski, P. Development, characterization, and bioactivity of non-dairy kefir-like fermented beverage based on flaxseed oil cake. Foods 2019, 8, 544. [CrossRef]

134. Xu, J.; Jonsson, T.; Plaza, M.; Hakansson, A.; Antonsson, M.; Ahren, I.L.; Turner, C.; Spegel, P.; Granfeldt, Y. Probiotic fruit beverages with different polyphenol profiles attenuated early insulin response. Nutr. J. 2018, 17, 34. [CrossRef] [PubMed]

135. Vergara-Salinas, J.R.; Bulnes, P.; Zuniga, M.C.; Perez-Jimenez, J.; Torres, J.L.; Mateos-Martin, M.L.; Agosin, E.; Perez-Correa, J.R. Effect of pressurized hot water extraction on antioxidants from grape pomace before and after enological fermentation. J. Agric. Food Chem. 2013, 61, 6929-6936. [CrossRef] [PubMed]

136. Zambrano, A.; Raybaudi-Massilia, R.; Francisco, A.; Sojo, F.; Martirosyan, D. Cytotoxic and antioxidant properties in vitro of functional beverages based on blackberry (Rubus glaucus B.) and soursop (Annona muricata L.) pulps. Funct. Foods Health Dis. 2018, 8, 520-536. [CrossRef]

137. Rovinaru, C.; Pasarin, D. Application of microencapsulated synbiotics in fruit-based beverages. Probiotics Antimicrob. Proteins 2019. [CrossRef]

138. Tomar, S.; Anand, S.; Sharma, P.; Mandal, S. Role of probiotics, prebiotics, synbiotics and postbiotics in inhibition of pathogens. In The Battle against Microbial Pathogens: Basic Science, Technological Advances and Educational Programs; Méndez-Vilas, A., Ed.; Formatex Research Center: Badajoz, Spain, 2015; pp. 717-732.

139. Aguilar-Toalá, J.E.; Garcia-Varela, R.; Garcia,H.S.; Mata-Haro, V.; González-Córdova, A.F.; Vallejo-Cordoba, B.; Hernández-Mendoza, A. Postbiotics: An evolving term within the functional foods field. Trends Food Sci. Technol. 2018, 75, 105-114. [CrossRef]

140. Moradi, M.; Mardani, K.; Tajik, H. Characterization and application of postbiotics of lactobacillus spp. on Listeria monocytogenes in vitro and in food models. LWT Food Sci. Technol. 2019, 111, 457-464. [CrossRef]

141. Wegh, C.A.M.; Geerlings, S.Y.; Knol, J.; Roeselers, G.; Belzer, C. Postbiotics and their potential applications in early life nutrition and beyond. Int. J. Mol. Sci. 2019, 20, 4673. [CrossRef]

142. Barros, C.P.; Guimarães, J.T.; Esmerino, E.A.; Duarte, M.C.K.H.; Silva, M.C.; Silva, R.; Ferreira, B.M.; Sant'Ana, A.S.; Freitas, M.Q.; Cruz, A.G.; et al. Paraprobiotics and postbiotics: Concepts and potential applications in dairy products. Curr. Opin. Food Sci. 2020, 32, 1-8. [CrossRef]

143. Helkar, P.B.; Sahoo, A.K.; Patil, N.J. Review: Food industry by-products used as a functional food ingredients. Int. J. Waste Resour. 2016, 6. [CrossRef]

144. Singh, H. Nanotechnology applications in functional foods; opportunities and challenges. Prev. Nutr. Food Sci. 2016, 21, 1-8. [CrossRef]

145. Andreani, T.; Fangueiro, J.F.; José, S.; Santini, A.; Silva, A.M.; Souto, E.B. Hydrophilic polymers for modified-release nanoparticles: A review of mathematical modelling for pharmacokinetic analysis. Curr. Pharm. Des. 2015, 21, 3090-3096. [CrossRef] [PubMed]

146. Zielińska, A.; Ferreira, N.R.; Nowak, I.; Durazzo, A.; Lucarini, M.; Cicero, N.; El Mamouni, S.; Silva, A.M.; Santini, A.; Souto, E.B.; et al. Development and optimization of alpha-pinene-loaded solid lipid nanoparticles (SLN) using experimental factorial design and dispersion analysis. Molecules 2019, 24, 2683. [CrossRef] [PubMed]

147. Durazzo, A.; Nazhand, A.; Lucarini, M.; Atanasov, A.G.; Souto, E.B.; Novellino, E.; Capasso, R.; Santini, A. An updated overview on nanonutraceuticals: Focus on nanoprebiotics and nanoprobiotics. Int. J. Mol. Sci. 2020, 21, 2285. [CrossRef] [PubMed]

148. Grumezescu, A.M.; Holban, A.M. Volume 20: The Science of Beverages. In Nanoengineering in the Beverage Industry, 1st ed.; Alexandru, G., Alina, M.H., Eds.; Academic Press: Cambridge, UK, 2020; ISBN 9780128166772.

149. Ozdal, T.; Yolci-Omeroglu, P.; Tamer, E.C. Role of encapsulation in functional beverages. In Biotechnological Progressand Beverage Consumption; Grumezescu, A.M., Holban, A.M., Eds.; Woodhead Publishing, Elsevier: Cambridige, MA, USA, 2020; Volume 19, pp. 195-232.

150. Tamjidi, F.; Shahedi, M.; Varshosaz, J.; Nasirpour, A. Stability of astaxanthin-loaded nanostructured lipid carriers in beverage systems. J. Sci. Food Agric. 2018, 98, 511-518. [CrossRef]

151. Kamiloglu, S. Authenticity and traceability in beverages. Food Chem. 2019, 277, 12-24. [CrossRef] [PubMed]

152. Hill, D.; Sugrue, I.; Arendt, E.; Hill, C.; Stanton, C.; Ross, R. Recent advances in microbial fermentation for dairy and health. F1000 Res. 2017, 6, 751. [CrossRef] 
153. Tewari, S.; David, J.; Gautam, A. A review on probiotic dairy products and digestive health. J. Pharmacogn. Phytochem. 2019, 8, 368-372.

154. Santini, A.; Novellino, E.; Armini, V.; Ritieni, A. State of the art of ready-to use therapeutic food: A tool for nutraceuticals addition to foodstuff. Food Chem. 2013, 140, 843-849. [CrossRef]

(c) 